\title{
HERPETOLOGICAL NOTES FROM THE PUERTO RICO AREA
}

\author{
Chapman Grant, Major, United States Army.
}

\section{Hemidactylus}

The last number of this journal contained an article, "The Hemidactyls of the Puerto Rico Region". It was remarked that $H$. brookii utters a squeak when caught. Miss Adrienne Serrano of Vieques was requested to observe whether $H$. mabouia also squeaks. Under date of April 15, 1932 she states: "The salamandras are very swift and squeak when they are eaught, as a sign of protest. They try to protect themselves when pursued by hiding in eracks or the joints of the boards."

Miss Serrano's statement covers an interesting point. H. broolii favors stone or masonry exclusively in my experience, whereas $H$. mabonia is found inside of frame houses. I have also taken them under banana sheaths on St. John, which I here add to its range, having recently taken twenty-one specimens there, five on St. Thomas. and one on Water Island-a total of $101 \mathrm{H}$. brookii and $92 \mathrm{H}$. mabouia, all agreeing with the descriptions in the above mentioned article.

It is interesting to note that West, writing in 1793 on the reptiles of St. Croix, says Thecadactylus rapicaudus, a large gecko, "screams ugly when being caught'.

The reason that collections do not contain more specimens of Hemidactyls is the old story that nocturnal species are ustally poorly represented in collections, whether of birds or reptiles. I quote Alexander Wetmore in this statement.

Ameiva eleanorae sp. nov.

The subspecies Ameiva wetmorei eleanorae, described on page 48 of the last Journal, may be given full specific value for the following reason. An unexpected difference develops in counting the femoral pores. The original description of $A$. wetmorei gives; " 13 or 14 femoral pores". This agrees with my findings of 13.3 for wetmorei and 12.0 for eleanorae. It is believed this difference is sufficient to give the form full specific rank. 
ITHE JOURNAL OF THE DEPARTMENT OF AGRICULTURE OF P. R.

\begin{tabular}{|c|c|c|c|c|c|c|}
\hline Pores on 39 legs & 11 & 12 & 13 & 14 & 15 & Av. \\
\hline A. wetmorei. . & 0 & 8 & 15 & 13 & 3 & $\mathrm{~J} 3.3$ \\
\hline A. eleanorae........... & 10 & 19 & 10 & 0 & 0 & 12.0 \\
\hline
\end{tabular}

\section{Sphaerodactylus}

The last number of the Journal contains an article "Sphaerodactylus grandisquamis, A. Valid Species". In this is mentioned the similarity between $S$. macrolepis from St. Croix and $S$. danforthi deseribed in the July 1931 number of this Journal from Culebra and found also on Vieques. Since then I have taken of what would appear to be $S$. macrolepis 4 specimens from Water Island, 2 from Little St. James, 22 from St. John, and 6 from Congo Key. These have not yet been worked up in detail, but since not a single redhead male appears in this series of 34 , it strengthens the full specific validity of $S$. danforthi.

The last issue contained a chart for determining the Sphaerodactyls of the Puerto Rico Region. The usefulness of this chart has been shown by the addition, since its issue, of 738 specimens of the various species which all fit into the chart. A total of 1783 specimens.

\section{Mabuya semitaeniatus}

This species was reestablished in an article in the July 1931 number of this Journal on the strength of 35 specimens from Mona and 27 from Culebra. The evidence has since been greatly strengthened by securing 21 additional specimens from Mona, 60 from Culebra and 6 from Buck Island, St. Thomas, all agreeing perfectly with $M$. semitaeniatus. Two more specimens of $M$. sloanii, one from Puerto Rico and one from Hicacos Island, both typical, add to the evidence. It seems that $M$. sloanii is restricted to Puerto Rico. The total series studied numbers 149 specimens of $M$. semitaeniatus and 8 of $M$. sloanii. The favorite hiding place of $M$. semitaeniatus is in dense clumps of Opuntia Dillenii (Ker-Gawl.) Haw., and not O. repens Bello as stated in the July number. I am indebted to Mr. J. M. Ortiz of Culebra and Mr. Juan Ferran of Mona for most of these specimens.

\section{Anolis roosevelti}

The magnificent giant Anolis described in the July 1931 number of this Journal was the only specimen I had ever seen until recently when Mr. J. M. Ortiz sent another fine specimen. Comparing these 
two with my series of 52 Anolis cuvieri the difference is seen to be great. An outstanding difference was overlooked which should have been included in the diagnosis; i.e., loreal area decidedly sloping in A. rooseveltri and vertical in A. cuvieri. The tail fin is always deeply sealloped distally between rays in $A$. cuvieri and straight in $A$. roosevelti. The fin is much higher in the latter, the animal is 10 per cent larger and the color is gray-not green or brown as in A. cuvieri.

Apparently the young of $A$. cuvievi has never been recorded. My collection contains numerous small examples, about $80 \mathrm{~mm}$. snout to vent. The average adult is about 135 . The young has the head larger in proportion-contained less than three times in snout-to-vent, whereas the adult is contained more than three times. Aside from these proportional differences, the young is a replica of the parents and in no way resembles $A$. evermanni, of which specimens nearly as large as these young $A$. cuvieri are common.

\section{Leptodactylus pentadactylus}

The Report of the Puerto Rico Agrieultural Experiment Station, Mayagïez, October 1930, p. 4, states: "During the year a dozen frogs (Leptodactylus pentadactylus) were introduced from Dominica, where they are known as "mountain chicken". They have been released near Mayagüez in the hope that they will serve as destrovers of insects and also prove valuable as food product."

T. B. McClelland, director of the station, wrote under date of April 14, 1931: "Op to the present time, we have not retrieved any specimens of this frog, though the people who live along the Cartagena Lagoon, where these were turned loose, say that they hear them."

Dr. Stuart Danforth conducted me on December 28, 1931 to the Cartagena Lagoon. We waited at the edge of the lagoon until well after dark but heard only Bufo marimus and concluded that this is what the natives referred to since the introduction of this toad is a comparatively recent occurrence (1920).

It might have been better to introduce this frog in a situation more nearly resembling its native habitat. Another attempt should be made and a larger number of specimens liberated.

It seems strange that the voice of Bufo marinus is not more frequently heard, although the toads are legion. The first time I heard it was from a military camp at Juncos after a year's residence on the Island. Shortly after dark a distant (?) noise started, which at 
first we attributed to a motorcycle, and later, when it seemed to remain stationary, we variously analyzed it as a feed chopper on one of the numerous dairies or an air drill in a quarry some two miles away. The noise started about dark and suddenly stopped shortly before daylight. A week later we eamped in the same place. Captain Saulnier stepped 'out of the camp about daylight and then realized that the noise was nearby. A week later we heard the noise again near Cataño. A flashlight showed the author to be Bufo marinus.

The toad stands with the membrane under the ehin vibrating but not distended; suddenly the vibration ceases; the throat and chest are moderately distended in a sweeping curve from the jaw to belly, to a size about equal to the head. The skin vibrates and a resonant sound is produced: "ku-ku-ku". The notes are slower than a trill and faster than one can enunciate them. These notes were made in November during very rainy weather and near semipermanent water.

\section{Anolis poncensis, A. pulchellus and A. krugi}

Stejneger shows two classes of markings, 'on Anolis poncensis, one in the extremely dry, hot and almost grassless environment, and the other amid greener surroundings. All A. poncensis, Stejneger, are marked with a white stripe commencing on the side of the snout, widening under the eye and across ear, more or less bordered with black to back of shoulder, where white line generally ceases. Above this stripe is one which commences above the eye and is interrupted by two dark loops bordered with white arising from lateral line on each side and running to the median line.

The first is divided into three phases-a drab one with the lateral lines and loops, a striped one, dark brown, black, and white. This form has a wide white median stripe arising between eyes and extending onto tail. A black line between this and an upper white lateral line, then a dark brown stripe, then the lateral white line arising on side of snout, then a light brown stripe, and then white 'of belly. The third is a spotted form wherein the neck loops are continued along the body as two rows of rings between median and lateral lines. In greener surroundings the color is perfectly deseribed by Stejneger except for the bright greenish yellow phase which is sometimes seen.

My most interesting observation is that the outer edge of the iris is bright steel blue. It is interesting that one species of this group and one of the cristatellus group (gundlachi) should have blue eyes. 
The blue is visible on a freshly killed specimen only by making the eye bulge by pressure from the opposite side. My only addition to the color description of $A$. krugi is that they are frequently seen solid so'oty black above, like cristatellus. The dorsal black dots are specific, in A. krugi immediately separating this from the other two slender species. Also the heavier head is immediately recognized.

In $A$. pulchellus I add that the center of the fan is purplish in Puerto Rico, the rest crimson.

My series contains 62 specimens of $A$. poncensis, 45 of krugi, and 162 pulchellus. The range of $A$. poncensis was considerably increased when on September 6, 1931, 21 specimens were taken along the road between Aguierra and Jabos. On April 3, 1932, in company with Dr. N. L. Britton, both species were found in the same field two miles west of Coamo Springs-A. poncensis occupying the fence posts and $A$. pulchellus the brush. The male $A$. poncensis had the scales of the vestiginal fan, a bright straw yellow.

A ready means of separating alcoholics is: A. krugi, numerous black dots above and usually below prominent white lateral line; $A$. pulchellus, usually a few vertical yellow marks, outlined in dark, above and frequently some below lateral white line; $A$. poncensis, oblique marks 'on nape, lateral white line short. This failing, coarse dorsals. 